\title{
KINETICS OF POLYMER CARRIER IMPREGNATION BY TRIALKYLAMINE
}

\section{КИНЕТИКА ИМПРЕГНИРОВАНИЯ ПОЛИМЕРНОГО НОСИТЕЛЯ ТРИАЛКИЛАМИНОМ}

\author{
TROSHKINA, I. D. ${ }^{*} ;$ OBRUCHNIKOVA, J. A. ${ }^{2}$; VESELOVA, O. A. ${ }^{2}$ PESTOV, S. M. ${ }^{1}$ \\ ${ }^{1}$ Dmitry Mendeleev University of Chemical Technology of Russia, Department of Expert Examination in Drug \\ Testing and Narcoanalysis \\ 20 Geroyev Panfilovtsev St., Moscow, 125480, Russian Federation \\ ${ }^{2}$ Moscow Technological University, Department of Physical Chemistry \\ 86 Vernadsky Ave., Moscow, 119454, Russian Federation \\ ${ }^{*}$ Corresponding author \\ tid@rctu.ru
}

Received in 20 September 2018; received in revised form 02 December2018; accepted 13 December 2018

\section{RESUMO}

O imediatismo do problema em estudo deve-se à falta de dados sobre a cinética de impregnação de transportadores de polímeros com agentes de extração. O objetivo deste artigo é obter as características cinéticas da impregnação de um transportador macroporoso polimérico - uma resina catiônica fracamente ácida com grupos carboxila - com trialquilamina e suas soluções em acetona. As curvas cinéticas integrais da adsorção do agente extrator no transportador foram obtidas. Isso permitiu estimar o tempo de equilíbrio pelo método de volume de solução limitado. Esse tempo foi de 25 a 30 horas, diminuindo com a aplicação de um agente de diluição e com o aumento da temperatura. As características cinéticas de impregnação foram calculadas por meio dos modelos de pseudo-segunda ordem, Elovich e difusão interna. O modelo de pseudosegunda ordem descreve os dados cinéticos experimentais com alto grau de correlação $\left(R^{2} \quad 0,995-0,997\right)$ e aponta que a interação com dois centros de sorção possivelmente ocorre com a adsorção de uma única molécula de trialquilamina. As constantes de taxa de impregnação através de um agente de extração foram calculadas usando todos os modelos cinéticos. Com base na magnitude da energia de ativação aparente ( $37 \pm$ $14 \mathrm{~kJ} / \mathrm{mol}$ ), pode-se assumir que a difusão é o passo limitante do processo de impregnação. Este artigo pode ser útil para criar impregnados contendo agentes de extração de várias classes.

Palavras-chave: cinética, impregnação, transportador polimérico macroporoso, trialquilamina, modelos cinéticos.

\section{ABSTRACT}

The immediacy of the problem under study is due to the lack of data on the kinetics of polymer carrier impregnation with extraction agents. The article is aimed at obtaining the kinetic characteristics of the impregnation of a polymeric macroporous carrier-a weakly acidic cation resin with carboxyl groups-with trialkylamine and its solutions in acetone. The integral kinetic curves of the extraction agent adsorption on the carrier were obtained. This allowed estimating the time of equilibrium by the limited solution volume method. This time was 25-30 hours, decreasing with the application of a dilution agent and with the increase in temperature. The kinetic impregnation characteristics were calculated by means of the pseudo-second-order, Elovich, and internal diffusion models. The pseudo-second-order model describes the experimental kinetic data with a high correlation degree $\left(\mathrm{R}^{2}\right.$ 0.995-0.997) and points out that interaction with two sorption centres possibly takes place with the adsorption of a single trialkylamine molecule. The impregnation rate constants via an extraction agent were calculated using all kinetic models. Based on the apparent activation energy magnitude $(37 \pm 14 \mathrm{~kJ} / \mathrm{mol})$, it can be assumed that diffusion is the rate-limiting step of the impregnation process. This article can be useful for creating impregnates containing extraction agents of various classes. 
Keywords: kinetics, impregnation, macroporous polymeric carrier, trialkylamine, kinetic models.

\section{АННОТАЦИЯ}

Актуальность исследуемой проблемы обусловлена отсутствием данных по кинетике импрегнирования (пропитывания) экстрагентами полимерных носителей. Статья направлена на получение кинетических характеристик импрегнирования полимерного макропористого носителя слабокислотного катионита с карбоксильными группами триалкиламином и его растворами в ацетоне. Методом ограниченного объема раствора получены интегральные кинетические кривые адсорбции экстрагента на носителе, позволяющие оценить время установления равновесия. Это время составило 25-30 ч, уменьшаясь при использовании разбавителя, а также повышении температуры. С помощью моделей псевдо-второго порядка, Еловича и внутренней диффузии рассчитаны кинетические характеристики процесса импрегнирования. Модель псевдо-второго порядка, по которой экспериментальные кинетические данные описываются c высокой степенью корреляции $\left(\mathrm{R}^{2}\right.$ 0,995-0,997), указывает на то, что при адсорбции одной молекулы триалкиламина происходит, возможно, взаимодействие с двумя сорбционными центрами. Рассчитаны константы скорости импрегнирования экстрагентом при использовании всех кинетических моделей. Исходя из величины

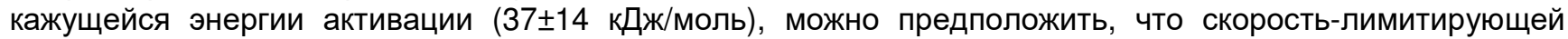
стадией процесса импрегнирования является диффузия. Материалы статьи могут быть полезными при создании импрегнатов, содержащих экстрагенты различных классов.

Ключевые слова: кинетика, импрегнирование, макропористый полимерный носитель, триалкиламин, кинетические модели.

\section{INTRODUCTION}

Sorption and extraction processes are widely used for the recovery and concentration of elements. Sorption of the elements, usually from dilute solutions, is carried out with the use of synthetic resins, activated carbons, inorganic sorbents, fibres and other materials (Dragan, 2015; Free, 2013; Kabay et al., 2010; Kauckzor and Meyer, 1978; Kosandrovich and Soldatov, 2012; Laskorin, 1989; Meretukov, 1980; Mukhin et al., 2000; Myasoedova and Nikashina, 2006; Warshawsky, 1981; Warshawsky and Cortina, 2002; Zagorodni, 2007). Extraction agents often in the form of a solution in an organic diluent - are applied for the liquid-phase extraction.

Sorption materials used in hydrometallurgy should have good kinetic characteristics. The time of establishing the sorption equilibrium during metal extraction via granular synthetic ion exchangers usually exceeds 4-6 hours. The fibrous ion exchangers possess the best kinetic properties, but the problems of instrumentation to use them are not completely solved at the moment.

Materials, whose properties are found between sorbents and extractants, are used for the extraction, separation, and concentration of elements. They are mainly obtained by means of impregnating the porous matrix with an extractant. Impregnated materials are called 'Solvent Impregnated Resins' (SIR). Polymeric carriers, ion exchangers, activated carbons, silica gel and other synthetic and natural materials are used as a porous matrix. The impregnates with the applied extractant are widely used in extraction chromatography.

In terms of density, bulk density, mechanical strength, the impregnates are similar to sorbents, and the mechanism of component extraction by the impregnates is similar to the extractive mechanism. The capacitive and kinetic characteristics of these materials are mainly determined by the porous structure, type, and state of the extraction agent in the matrix (Kabay et al., 2010; Warshawsky and Cortina, 2002; Zagorodni, 2007).

The absence of a chemical bond between the extraction agent and the polymer matrix is a 
characteristic feature of the impregnates. Due to the mobility of the liquid phase, these materials have improved kinetic characteristics.

The application of such materials makes it possible to exclude toxic and fire hazardous organic diluents provides means for carrying out the processes of extraction from non-clarified solutions and pulps and ensures the reduction of the contamination of raffinates and sewage waters with organic reagents in comparison with the liquid extraction.

The production method associated with the use of extractant solutions in an organic diluent, whose role consists in swelling and loosening the polymer base, has become the most widespread among the known methods of creating such materials.

The organic phase can either completely fill the carrier pores or be distributed over its surface in the form of a film, depending on the application technique and the amount of injected extractant (Meretukov, 1980).

The purpose of a carrier is the ability to tightly hold the mobile phase. In this respect, it must meet the following requirements: to be well wetted by mobile phase; to be chemically inert, not to react with the mobile phase, not to absorb the components being extracted; to have the particles of the same size and shape, better spherical, which contributes to the most uniform and reproducible column filling; to have a sufficient surface for the mobile phase, to be evenly distributed in the form of a thin film; to have sufficient mechanical strength.

The carriers may be divided into two main large groups.

The carriers, whose surface is covered with hydroxyl groups, belong to the first group. Such substances have high surface energy and can be well wetted by such strongly polar liquids as water only. This group includes mainly inorganic materials, such askieselguhrs, silica gels, glass, aluminum oxide, cellulose. Their general disadvantage lies in the fact that the hydroxyl groups themselves are capable of ion exchange. Besides, these carriers can retain a limited number of extractants only.

Various polymer materials that have low surface energy and are well wetted with various organic solvents may be referred to the second group.

The composition of various carriers and extractants is rather well studied, and the rationale for their choice is usually available. However, there is almost no information on the kinetics of carrier impregnation by an extractor determining and conditions of the impregnation the process. This paper aims to fill this gap.

The objective of this research is to define the kinetic impregnation characteristics of a polymeric macroporous carrier in case of impregnation with trialkylamineextractant-(TAA).

\section{MATERIALS AND METHODS}

Reagents. Technical TAA $\left(\mathrm{R}_{3} \mathrm{~N}\right)$ was used as an extractant, where $\mathrm{R}=\mathrm{C}_{n} \mathrm{H}_{2 n+1}, n=8-10$, whose properties corresponded to those stated in TU 2413-003-48590531-2009. Acetone of chemically pure grade was used to prepare the TAA solution.

Spherically granulated, macroporous, weak-acid cation resin on an acryl-divinylbenzene base containing carboxyl groups (TU 2227-01972285630-2009-2009) was used as a polymeric carrier. The size of its granules was $(0.63 \div 1.6)$ $\mathrm{mm}$.

Methodology.Impregnation of a polymer carrier was fulfilled by the limited solution volume method (Kokotov and Pasechnik, 1979) in excess of extractant or its solution in acetone under the static conditions. For that, a sample of the airdried carrier $(1 \mathrm{~g})$ was put in contact with $2 \mathrm{ml}$ of TAA or $4 \mathrm{ml}$ of its solution in acetone (the ratio of TAA and acetone volumes was 1:1) with gentle mixing on the LAB-PU-01 shaking apparatus (30 rpm) for a certain time period. The impregnation time was from 10 to $1440 \mathrm{~min}$. The carrier, saturated with the extractant, was transferred to the vacuum filter and washed with $10-15 \mathrm{~cm}^{3}$ of distilled water upon the expiration of adsorption time. The drying of impregnating washed free of the excess of the extractant, was accomplished in a drying chamber at a temperature of $50^{\circ} \mathrm{C}$ for 5 hours.

When studying the influence of temperature on the impregnation process, the carrier samples were in contact with TAA in a thermostated cell at a temperature of $50{ }^{\circ} \mathrm{C}$ (calibration error: $\pm 0.1^{\circ} \mathrm{C}$ ).

The TAA content in the impregnate was evaluated based on the difference in weight of the initial polymer and the obtained impregnate 
(under equilibrium conditions) according to the following formula:

$$
\omega=\left(m_{i m p}-m_{\text {ini }}\right) / m_{\text {imp }} \cdot 100 \%,
$$

where $\omega$ is the extractant mass fraction in the

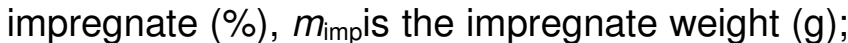
$m_{\text {ini }}$ is the primary carrier mass $(g)$.

The impregnation rate was estimated based on the behaviour of the impregnate sorption capacity in time. The process behaviour can be examined with the help of a metal. Rhenium was chosen for this purpose since TAA is widely used for its extraction, and the isotherm of sorption by the rhenium-based impregnate is linear in a wide range of the equilibrium concentrations of rhenium (Palant, 2015, p. 151).

Rhenium sorption by the impregnated samples, saturated during the above-mentioned period of time, was carried out from the sulfuric acid solutions ( $\mathrm{pH} 2)$, containing $100 \mathrm{mg} / \mathrm{dm}^{3}$ of rhenium, under static conditions. Prior to sorption, each impregnate sample was put in contact with a solution having the same $\mathrm{pH}$ value as the initial solution, prepared for the sorption. The time of contact was $30 \mathrm{~min}$. The solution $\mathrm{pH}$ value was determined using SevenEasypH $\mathrm{pH}$ meter (Mettler Toledo). Then, the impregnate was separated from the solution and put in contact with the solution containing rhenium with a ratio of impregnate phases to solution of $1: 1000(0.1 \mathrm{~g}$ of sorbent: $100 \mathrm{~cm}^{3}$ of solution) on the LAB-PU-01 shaking apparatus (120 rpm) for 4 hours, or for 12 hours without shaking. The phase separation was performed, and the liquid phase was filtered through a 'white tape' filter after the contact. The resulting solution was analyzed for rhenium content by the photometric method with rhodanate complexes (Borisova and Ermakov, 1974) using the KFK-03-01 concentration photoelectric photometer (Experimental Optomechanical Plant, Russia). The impregnate sorption capacity (CE, mg/g) was calculated according to the balance ratio:

$$
\mathrm{CE}=\left(C_{i n i}-C_{c o n}\right) \cdot V_{\text {sol }} / g,
$$

where CE is the sorption capacity $(\mathrm{mg} / \mathrm{g}) ; C_{\text {inils }}$ the concentration in the initial solution $(\mathrm{mg} / \mathrm{l}) ; C_{\text {con }}$ is the concentration in the solution after sorption $(\mathrm{mg} / \mathrm{l}) ; V_{\text {sol }}$ is the solution volume $\left(\mathrm{dm}^{3}\right) ; g$ is the sorbent sample weight $(\mathrm{g})$.

To process the kinetic data on TAA impregnation, the data on impregnate capacity of rhenium was used. These data were recalculated through the saturation degree $F(\%)$, which was determined by the following equation:

$$
F=C E / C_{\text {equal }} \bullet 100,
$$

where $C E_{\text {equal }}$ is the capacity of the rhenium impregnate being observed when the equilibrium is reached during the impregnation.

\section{RESULTS AND DISCUSSION}

Integral kinetic curves in the CE - $t$ coordinates, where $t$ is the impregnation time (Fig. 1), were obtained to determine the optimal impregnation time of the polymer carrier with TAA and its solution in acetone.

The data analysis in Fig. 1 shows that the equilibrium in the carrier/extractant system occurs after 25-35 hours. The presence of a diluent (acetone) contributes to an increase in the impregnation rate. In this case, the process of TAA diffusion into the carrier is accompanied by the process of polymer carrier swelling in the presence of acetone, which promotes the adsorption of its larger amount per unit time as compared with the original extractant diffusion.

The increase in the impregnation temperature (Fig. 2) also contributes to the increase in its rate.

Apparently, a decrease in the extractant viscosity also contributes to this.

Mathematical processing of the experimental kinetic data was performed in accordance with the models of sorption kinetics that describe the diffusion and the mechanism of interaction of various numbers of molecules in the process by means of linearizing them according to the following equations (Azizian, 2004; Foo and Hameed, 2010; Helfferich, 1962; Ho, 2006; Tran, et al., 2017):

\section{Pseudo-first-order model}

$\lg (Q e-Q t)=\lg Q e-\left(k_{1} /(2.303 t)\right.$ 


\section{Pseudo-second-order model}

$$
t / Q t=1 /\left(k_{2} \cdot Q e^{2}\right)+1 / Q e t \quad(E q .5)
$$

3. Internal diffusion model

$$
Q t=k_{i d} t^{0.5}+C
$$

\section{Elovich model}

$$
Q t=1 / \beta \cdot \ln (\alpha \cdot \beta)+1 / \beta \cdot \ln (t),(\text { Eq.7) }
$$

where $Q e$ is the equilibrium sorption capacity $(\mathrm{mg} / \mathrm{g})$; $Q t$ is the sorption capacity at time $t(\mathrm{mg} / \mathrm{g}) ; k_{1}\left(k_{2}\right)$ is the rate constant of the pseudo-first (pseudo-second) order $\left(\mathrm{min}^{-1}(\mathrm{~g} \cdot \mathrm{mg}\right.$ $\left.\left.{ }^{1} \cdot \mathrm{min}^{-1}\right)\right) ; k_{\text {id }}$ is the internal diffusion rate constant $\left(\mathrm{mg} \cdot \mathrm{g}^{-1} \cdot \mathrm{min}^{-0.5}\right) ; \alpha$ is the sorption process initial rate $\left(r \cdot \mathrm{mg}^{-1} \cdot \mathrm{min}^{-1}\right) ; \beta$ is the Elovich rate constant $\left(r \cdot \mathrm{mg}^{-1}\right)$.

The graphical representation of the mathematical data processing results according to these models is presented in Fig. 3-6.

According to the correlation coefficient values, the kinetic impregnation curves can be best described with the pseudo-second-order model, the Elovich model, and the internal diffusion model.

Apparently, interaction with two sorption centres takes place during the adsorption of a single TAA molecule in accordance with the pseudo-second order model.

The Elovich model is used for the description of adsorption processes, so it can be assumed that the physical adsorption of the extractant on the carrier's inner and outer surfaces is a limiting stage while impregnating. The internal diffusion model suggests that the internal diffusion of TAA in the pores of the polymeric matrix can be one of the process limiting stages.

The velocity constants and the correlation factors of the linearized lines, describing the impregnation process for the selected models are presented in Table 1.

According to the constants values (Table
1) obtained while describing the integral kinetic curves according to the pseudo-second-order model equation, the impregnation rate increase is observed at a temperature effect. On the contrary, the injection of a diluent (acetone), reduces the TAA layer formation rate of the polymer carrier surface despite the fact that the extractant solution is less viscous in the diluent.

The value of apparent energy ( $E_{\text {app }}$, $\mathrm{kJ} / \mathrm{mol}$ ) of the sorption activation was calculated from the dependence $\operatorname{lnk}=\mathrm{f}\left(\mathrm{T}^{-1}\right)$, which follows from the Arrhenius equation. The calculation was based on the formula below, using the rate constants obtained when employing the pseudosecond-order equation:

$$
E_{\text {app }}=\left(R \cdot \ln \left(k_{1} / k_{2}\right) \cdot T_{1} \cdot T_{2}\right) /\left(T_{2}-T_{1}\right)
$$

where $R$ is the universal gas constant $(\mathrm{J} /(\mathrm{mol} \cdot \mathrm{K}))$; $k_{1}$ and $k_{2}$ are the rate constants at a temperature $T_{1}$ and $T_{2},\left(\mathrm{~g} \cdot \mathrm{mg}^{-1} \cdot \mathrm{min}^{-1}\right) ; T_{1}$ is the temperature (295 K); $T_{2}$ is the temperature (323K).

Based on the obtained value of the apparent activation energy $(37 \pm 4 \mathrm{~kJ} / \mathrm{mol})$, it can be assumed that the diffusion is a rate-limiting stage of an impregnation process. The pseudosecond-order model, by which the experimental kinetic data is described with a high correlation degree $\left(R^{2}\right.$ 0.995-0.997), points out that the interaction with two sorption centres possibly takes place while the adsorption of a single TAA molecule is in progress.

\section{CONCLUSIONS:}

The kinetic data obtained by the limited solution volume method made it possible to determine the optimal impregnation time of a macroporous polymeric carrier with technical TAA, that is 25-35 h. The presence of a highly volatile diluent (acetone) contributes to the reduction of the extractant layer formation rate on the carrier surface, thereby decreasing the sorption characteristics over time. On the contrary, the temperature increase leads to the increase in the impregnation rate, since the extractant viscosity reduces without the injection of additional components of the organic phase (diluent). This can be confirmed by the rate 
constants, calculated according to the data of linearized integral kinetic curves with the aid of a pseudo-second-order model.

The impregnation process takes place in the diffusion region since the apparent activation energy of the process is relatively low $(37 \pm 4$ $\mathrm{kJ} / \mathrm{mol}$ ). However, the kinetic data, described with a high degree of correlation by means of the pseudo-second order and Elovich models, is indicative of the contribution of TAA physical adsorption on the carrier and the possible interaction of the extractant molecule with two sorption centres of the carrier.

To shorten the impregnation time, it is reasonable to carry out the process of obtaining impregnates at an elevated temperature.

\section{ACKNOWLEDGEMENTS:}

This research was partially funded by the Ministry of Education and Science of the Russian Federation under the Subsidy Agreement No. 14.580.21.0004 of 19.08.2015 (project identification number RFMEFI58015X0004).

\section{REFERENCES:}

1. Azizian, S.; Journal of Colloid and Interface Science 2004, 276, 47.

2. Borisova, L. V.; Ermakov, A. N.; Analytical chemistry of rhenium, Khimiya: Moscow, 1974.

3. Dragan, E. S., ed.; Advanced separations by specialized sorbents, CRC Press: Boca Raton, 2015.

4. Foo, K. Y.; Hameed, B. H.; Chemical Engineering Journal 2010, 156, 2.

5. Free, M. L.; Hydrometallurgy. Fundamentals and applications, John Wiley \& Sons: Hoboken, 2013.

6. Helfferich, F.; lonites. Fundamentals of ion exchange, Inostrannaya literatura: Moscow, 1962.

7. Ho, Y. S.; Review of second-order models for adsorption systems, J. of Hazardous Materials 2006, B136, 681.

8. Kabay, N.; Cortina, J. L.; Trochimczuk, A.;
Streat, M.; React. Funct. Polym. 2010, 70(8), 484.

9. Kauckzor, H. W.; Meyer, A.; Hydrometallurgy 1978, 3, 65.

10. Kokotov, Yu.A.; Pasechnik, V. A.; Ion exchange equilibrium and kinetics, Khimiya: Leningrad, 1979.

11. Kosandrovich, E. G.; Soldatov, V. S.; Fibrous Ion Exchangers; Inamuddin; Luqman, M., eds.; Ion Exchange Technology I: Theory and Materials, Springer Science+Business Media B.V., 2012, 299.

12. Laskorin, B. N., ed.; lon-exchange materials for hydrometallurgy, wastewater treatment and water conditioning processes, All-Russian Scientific Research Institute of Chemical Technology: Moscow, 1989.

13. Meretukov, M. A.; Application of impregnated materials for extraction and separation of non-ferrous metals, Review. Inform. TsNIIEITsM 1980, 3.

14. Mukhin, V. M.; Tarasov, A. V.; Klushin, V. N.; Active coals of Russia, Metallurgy: Moscow, 2000.

15. Myasoedova, G. V.; Nikashina, V. A.; Russian Chemistry Journal 2006, 50(5), 55.

16. Palant, A. A.; Troshkina, I. D.; Chekmarev, A. M.; Kostylev, A. I.; Rhenium technology, Galleya-Print: Moscow, 2015.

17. Tran, H. N.; You, S.-J.; HosseiniBandegharaei, A.; Chao, H.-P.; Water Research 2017, 120, 88.

18. Warshawsky, A.; Cortina, J. L.; Proc. of the Intern. solvent extract. conf.: ISEC 2002.

19. Warshawsky, A.; Ion Exchange and Solvent Extraction 1981, 8(3), 229.

20. Zagorodni, A. A.; Ion Exchange Materials, Elsevier: Amsterdam, London, 2007. 
Table 1. Rate constant values of the TAA carrier impregnation

\begin{tabular}{|c|c|c|c|c|c|c|c|}
\hline \multicolumn{2}{|c|}{$\begin{array}{c}\text { Pseudo-first-order } \\
\text { model }\end{array}$} & \multicolumn{2}{|c|}{$\begin{array}{l}\text { Pseudo-second- } \\
\text { order model }\end{array}$} & \multicolumn{2}{|c|}{$\begin{array}{c}\text { Internal diffusion } \\
\text { model }\end{array}$} & \multicolumn{2}{|c|}{ Elovich model } \\
\hline $\mathrm{k}_{1}, \min ^{-1}$ & $\mathrm{R}^{2}$ & $\begin{array}{c}\mathrm{k}_{2}, \\
\mathrm{~g} \cdot \mathrm{mg}^{-1} \cdot \mathrm{min}^{-1}\end{array}$ & $\mathrm{R}^{2}$ & $\begin{array}{c}\mathrm{k}_{\mathrm{p}} \\
\mathrm{mg} \cdot \mathrm{g}^{-1} \cdot \mathrm{min}^{-0.5}\end{array}$ & $\mathrm{R}^{2}$ & $\beta, g \cdot \mathrm{mg}^{-1}$ & $\mathrm{R}^{2}$ \\
\hline \multicolumn{8}{|c|}{ Trialkylamine $(295 \mathrm{~K})$} \\
\hline 0.0011 & 0.862 & 0.00025 & 0.994 & 2.79 & 0.829 & 0.085 & 0.967 \\
\hline \multicolumn{8}{|c|}{ Solution of trialkylamine in acetone (295K) } \\
\hline 0.0019 & 0.592 & 0.00017 & 0.986 & 2.12 & 0.796 & 0.059 & 0.937 \\
\hline \multicolumn{8}{|c|}{ Trialkylamine (323K) } \\
\hline 0.0037 & 0.573 & 0.00091 & 0.998 & 1.37 & 0.745 & 0.133 & 0.902 \\
\hline
\end{tabular}

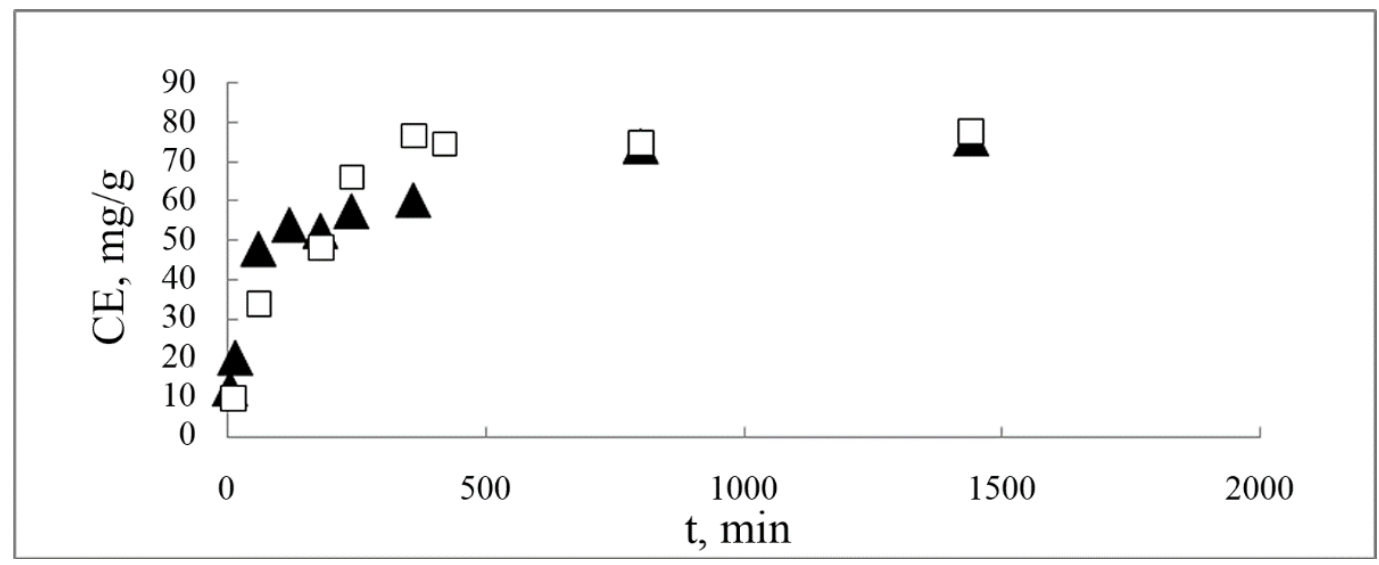

Figure 1. Kinetic curves of the cation exchanger impregnation with the TAA solution in acetone ( $\square$ ) and pure TAA (A)

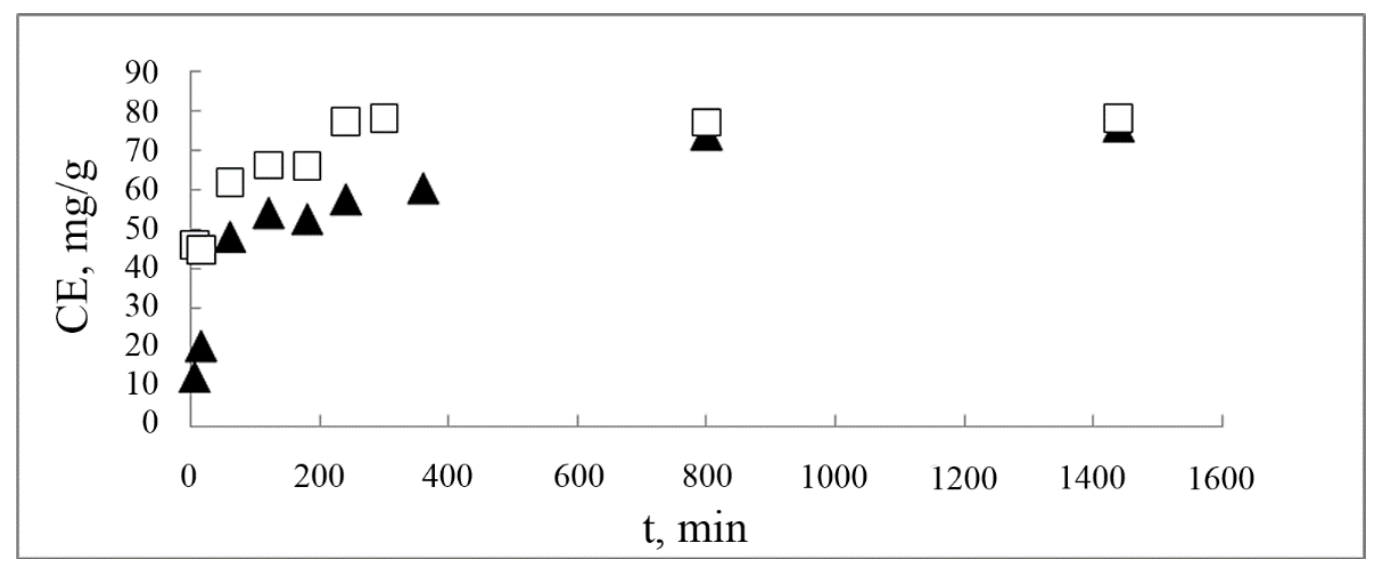

Figure 2. Kinetics of the cation exchanger impregnation with TAA at the temperatures of 295 ( $\mathbf{\Delta})$ and $323(\square) K$ 


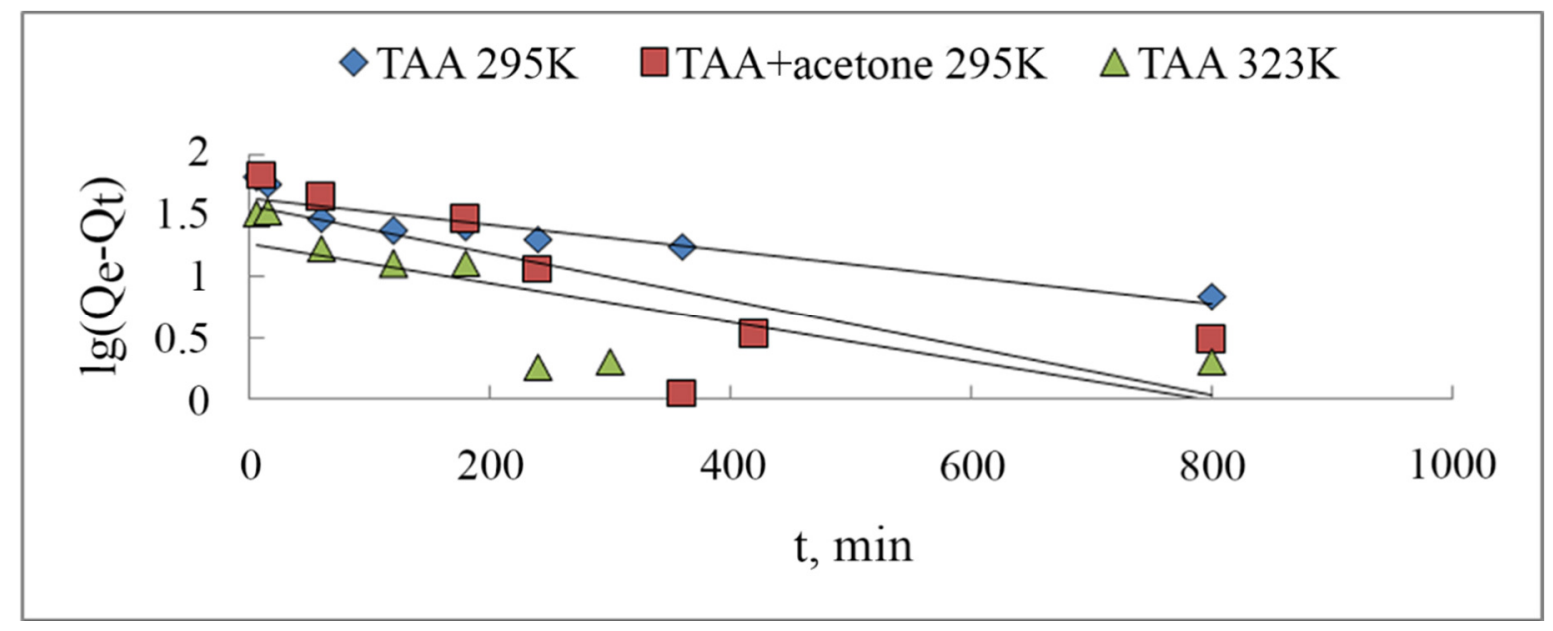

Figure 3. Dependence of $\lg \left(Q_{e}-Q_{t}\right)$ on time $t$ for the experimental data on TAA carrier impregnation

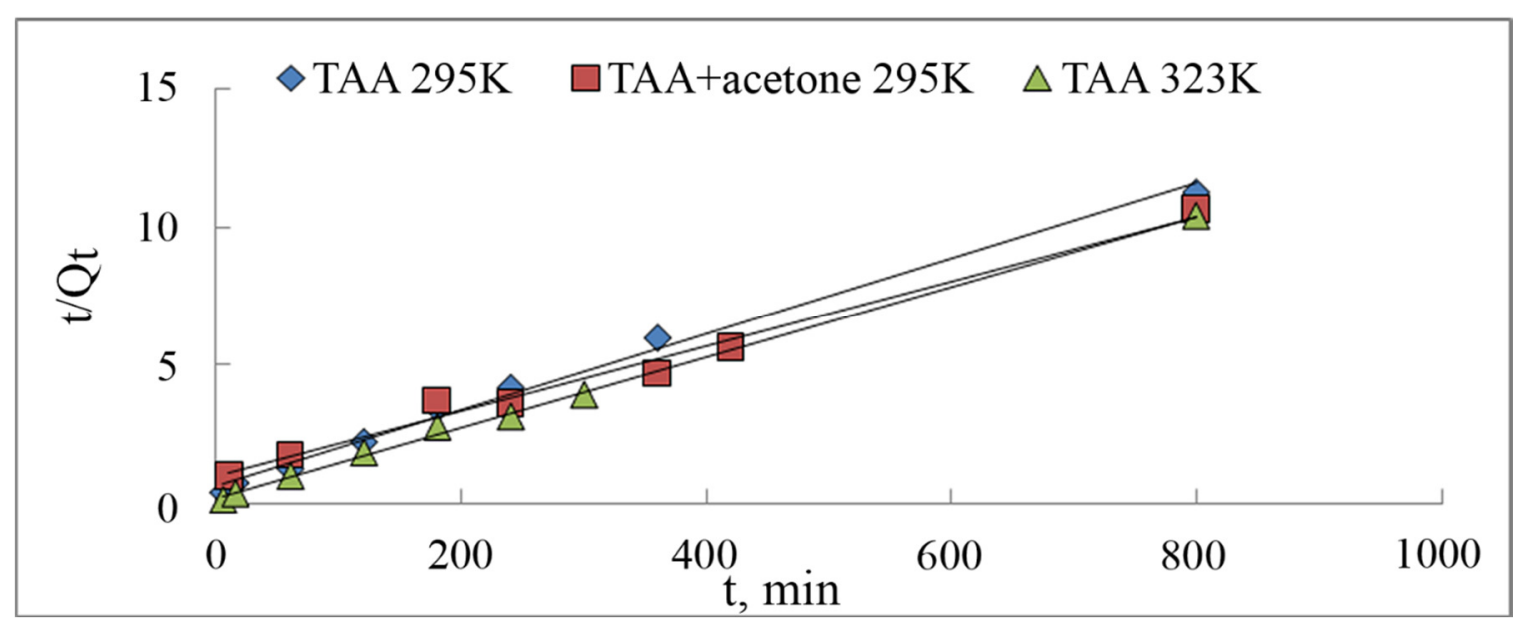

Figure 4. Dependence of $t / Q t o n$ time $t$ for the experimental data on TAA carrier impregnation

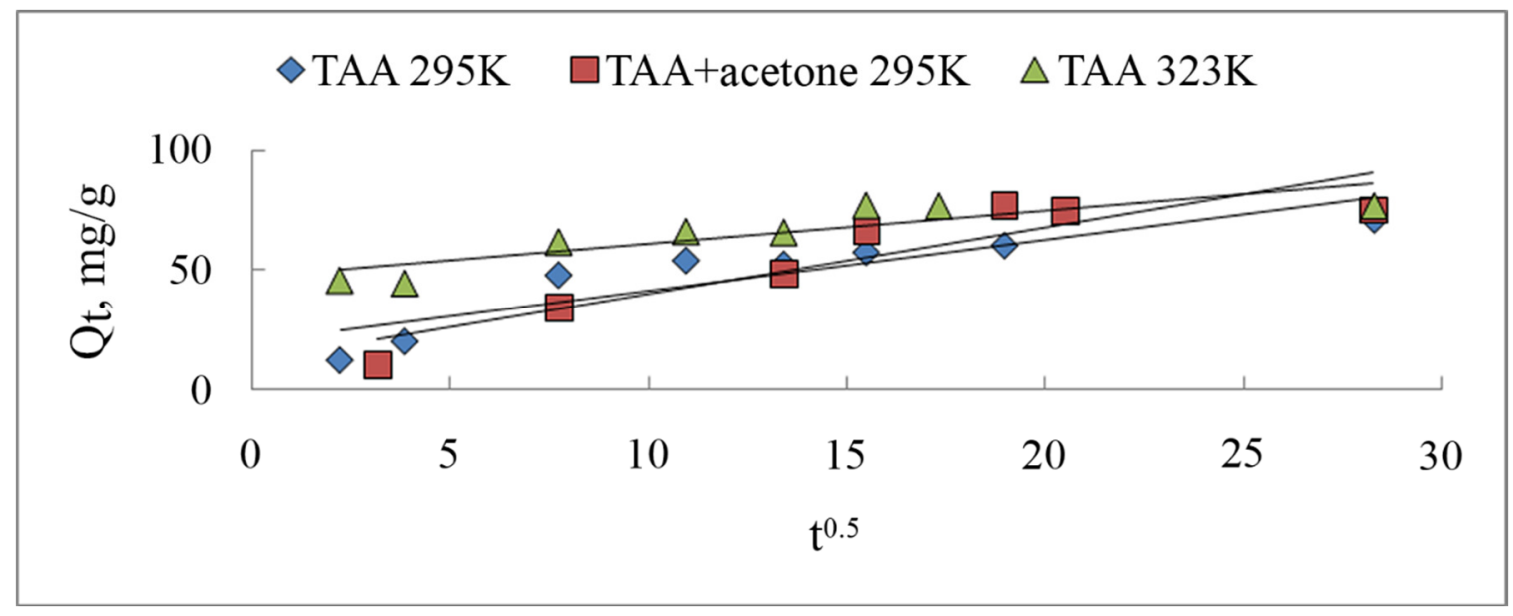

Figure 5. Dependence of Qt on $t^{0.5}$ for the experimental data on TAA carrier impregnation 


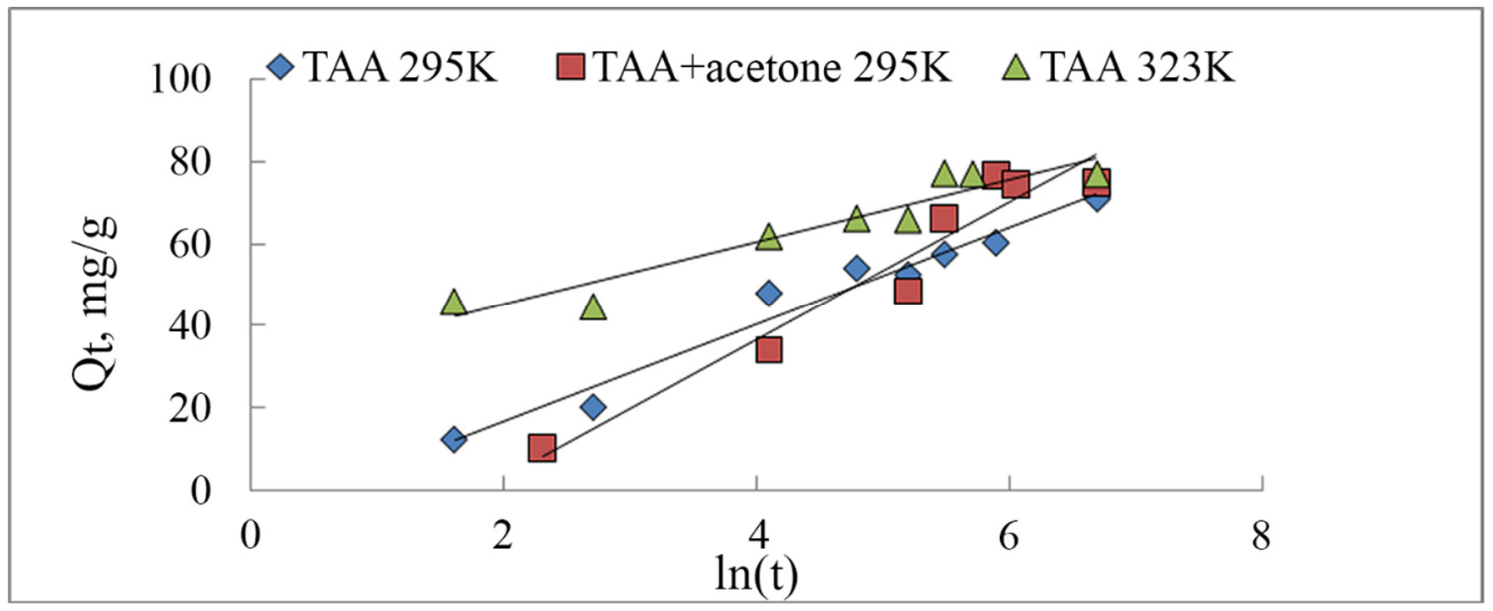

Figure 6. Dependence of Qton In(t) for the experimental data on TAA carrier impregnation

PERIÓDICO TCHÊ QUÍMICA•www.periodico.tchequimica.com• Vol. 16 N. 31.

• ISSN 1806-0374 (impresso) • ISSN 1806-9827 (CD-ROM)・ISSN 2179-0302 (meio eletrônico) (C) 2019. Porto Alegre, RS. Brasil

The Periódico Tchê Química (ISSN: 1806-0374; 2179-0302) is an open-access journal since 2004. Journal DOI: 10.52571/PTQ. http://www.tchequimica.com.

The Periodico Tchê Quimica (ISSN: 1806-0374; $2179-0302)$ is an open
This text was introduced in this file in 2021 for compliance reasons.
(C) The Author(s)

OPEN ACCESS. This article is licensed under a Creative Commons Attribution 4.0 (CC BY 4.0) International License, which permits use, sharing, adaptation, distribution, and reproduction in any medium or format, as long as you give appropriate credit to the original author(s) and the source, provide a link to the Creative Commons license, and indicate if changes were made. The images or other third-party material in this article are included regulation or exceeds the permitted use, you will need to obtain permission directly from the copyright holder. To view a copy of this license, visit http://creativecommons.org/licenses/by/4.0/. 